\title{
UTILIZING CARBON NANOTUBES AS EFFICIENT NANOADSORBENT FOR PANTOPRAZOLE REMOVAL FROM AQUEOUS SAMPLES: KINETICS, ISOTHERM, AND THERMODYNAMIC STUDIES
}

\author{
N. SADEGHPOUR, M. VADI * AND N. BAGHERI \\ Department of Chemistry, Firoozabad Branch, Islamic Azad University, Firoozabad, Iran.
}

\begin{abstract}
In this work, carbon nanotubes (MWCNTs) were utilized as efficient adsorbents for pantoprazole (PP) removal. We used MWCNTs that were synthesized using the chemical vapor deposition process. The physical characteristics of MWCNTs were described by Brunauer-Emmett-Teller (BET) contact area, surface functional group analysis by the point of zero charge ( $\mathrm{pH}_{\mathrm{PZC}}$ ), Fourier transform infrared (FTIR) analysis, Scanning electron microscope (SEM), X-ray diffraction (XRD), and Transmission electron microscopy (TEM). The single-point BET surface area of the MWCNTs was found to be $98.7 \mathrm{~m}^{2} \mathrm{~g}^{-1}$, with the median pores' diameter of 30.9 $\mathrm{nm}$ and an average pore(s) volume of $0.764 \mathrm{~cm}^{3} \mathrm{~g}^{-1}$. Effective parameters on the PP removal including, $\mathrm{pH}$, contact time and initial amount of adsorbents were optimized, revealing maximum PP removal at $\mathrm{pH}=6.0$ after $25.0 \mathrm{~min}$ when $0.026 \mathrm{~g}$ MWCNTs. The pseudo second-order kinetic model for adsorption of PP on the surface of both adsorbents revealed the high value of correlation coefficient, indicating the high ability of the pseudo second-order model for representation of experimental results. Adsorption equilibrium studies indicated that the Freundlich isotherm efficiently represented MWCNTs adsorption data. The thermodynamic parameters (Gebbs free energy, enthalpy, and entropy) of adsorption process were calculated. Results had shown that adsorption of PP on the MWCNTs is feasible, spontaneous, and exothermic process in the temperature range of $25-76^{\circ} \mathrm{C}$.
\end{abstract}

Keywords: Chemisorption, electrochemical exfoliation, exothermic, methylene blue, nano-graphene, Waste batteries (AA and AAA).

\section{INTRODUCTION}

These days, water waste of medicinal residues is actually a significant problem. Drug metabolites in water join human organisms and interact with many bio-activities. Hormone, enzyme, and hereditary are the most significant biological results [1]. Industrial wastewaters usually contain some nonbiodegradable water-soluble toxic wastes for instance, toxic dyes such as congo red [2] and methylene blue [3] and pharmaceutical active compounds (PhACs), for example, drug residues such as pantoprazole [4] and omeprazole [5]. MWCNTs with minor defects and positive traits may be available. Gained by laser ablation and, arc discharge but only in limited amounts. Even so, MWCNTs can be produced in large amounts Chemical vapor deposition (CVD) and the diameter, number of layers and growth MWCNTs are often easy to control in such a manner that MWCNTs are normally prepared by CVD, this method has become increasingly popular because of its high performance, high yield and pure MWCNTs [6]. Due to rapid advancement of MWCNTs on the catalytic converter (usually $\mathrm{Co}, \mathrm{Ni}, \mathrm{Fe}$, etc.) and the transformation of the metal-assisted catalyst Transformation of hydrocarbons (such as ethylene, methane, $\mathrm{CO}$, propylene, benzene, etc.). MWCNTs processed by CVD would include metal catalysts at one extreme and carbonaceous contaminants, such as amorphous carbon, polyhedral carbon, and aromatic carbon.

PhACs can play several biological roles in our body and therefore can affect our biological activities, for instance, enzymatic and hormonal, as well as genetic [7]. These wastes can make serious environmental damages [8,9]. The first water-soluble benzimidazole, 5-(difluoromethoxy)-2-[[(3,4-dimethoxy-2pyridinyl) methyl] sulfinyl]-benzimidazole. applied was pantoprazole (PP) which is one of the most widely used medicines in the world [10]. Roughly 70 to 95 percent of the PP usage is excreted into the urine and feces as metabolites that are inert or pharmaceutically active [11]. PP residues occur at levels up to $0.18 \mathrm{mgL}^{-1}[12,13]$ in household wastewaters. In this case, it is almost impossible to remove PP drug residues from water. It is thus necessary to stress that the removal of pantoprazole from water is not a finished available method [1].

A wide variety of experimental protocols, for example, photocatalytic degradation [14-16], filtration [17,18], reverse osmosis [19,20], biological treatment $[21,22]$, and adsorption [23,24] process have been utilized for water treatment. From many different methods of removal, adsorption is deemed to be the best one. This is the result of its being simple and cost-effective, non-toxic as well as easy to operation [2,25-27]. Recently, a wide variety of adsorbents such as modified activated carbons [28], metal organic [29] as well as magnetite/graphene oxide nano composite [30] have been utilized for drugs removal from waste water samples. MWCNTs are generally conceded to be an exceptionally suitable choice for the adsorption mechanism: this is in fact both the result of price reduction and a consequence of high-quality characteristics of MWCNTs [31].
In this research, inexpensive MWCNT compounds were synthesized using a standard Chemical vapor deposition (CVD) process. Additionally, our modified MWCNTs have acted as a promising candidate for PP adsorption. Effective parameters on removal efficiency including, $\mathrm{pH}$, contact time and initial amount of adsorbents were optimized. Kinetic models were employed to investigate the data corresponding to the adsorption of PP on the surface of MWCNTs. Adsorption equilibrium studies indicated that the Freundlich isotherm efficiently represented MWCNTs adsorption data. The thermodynamic of adsorption process was investigated.

\section{EXPERIMENTAL SECTION}

\subsection{Materials}

All the main chemicals used were of analytical grade. PP, sodium hydroxide $(\mathrm{NaOH})$, nitric acid $\left(\mathrm{HNO}_{3}\right)$, sodium chloride $(\mathrm{NaCl})$, Trisodium phosphate $\left(\mathrm{Na}_{3} \mathrm{PO}_{4}\right)$, sodium nitrate $\left(\mathrm{NaNO}_{3}\right)$, sodium sulfate $\left(\mathrm{Na}_{2} \mathrm{SO}_{4}\right)$ and hydrochloric acid $(\mathrm{HCl})$ were purchased from Merck Chemicals (Darmstadt, Germany) and used without any further purification. By dissolving the required amount of PP in a certain volume of distilled water, a stock solution of $\mathrm{PP}(1000 \mathrm{mg} / \mathrm{l})$ has been made. By diluting the stock PP solution with distilled water, working PP solutions were prepared. To change the $\mathrm{pH}$ of operating solutions to the appropriate amount, solutions of $\mathrm{NaOH}(0.1 \mathrm{M})$ and $\mathrm{HCl}(0.1 \mathrm{M})$ have been used.

\subsection{Apparatus}

High-performance liquid chromatography (HPLC) (Perkin-Elmer series 200; column $\mathrm{C}_{18}$, UV detector, $\lambda=291 \mathrm{~nm}$, USA), was used to PP concentration determination in solutions. Mobile phase consisted of phosphate/acetonitrile buffer, $\mathrm{pH} 7.4(65: 35 \mathrm{v} / \mathrm{v})$. A Metrohm $\mathrm{pH}$-meter (model: 827) was used for $\mathrm{pH}$ measurements. When we went through the examination of our samples' morphology, the methods we used were: Transmission Electron Microscopy (TEM) (Philips EM 208S, $100 \mathrm{kV}$, Netherlands), Fourier Transform Infrared Spectroscopy (FT-IR) (PerkinElmer, RX1, USA), Field Emission-Scanning Electron Microscopy (FE-SEM) (TESCAN, MIRA3, Czech Republic), Brunauer-Emmett-Teller (BET) (Microtrac Bel Corp CO. Japan), and Point of Zero Charge $\left(\mathrm{pH}_{\mathrm{pzc}}\right)$.

\subsection{Method}

All experiments were conducted in a closed, $50 \mathrm{~mL}$, glass, round-bottom flask. The flask, which contained the MWCNTs and $25.0 \mathrm{~mL}$ of the PP solution, was placed at $25{ }^{\circ} \mathrm{C}$ and mixed at $700 \mathrm{rpm}$ for $25 \mathrm{~min}$. The experiments to determine the effect of contact time were performed at $25{ }^{\circ} \mathrm{C}$ for contact periods ranging from 0 to 60 min using $1.0 \mathrm{~g} \mathrm{~L}^{-1}$ of MWCNTs and an initial PP concentration of $70.0 \mathrm{mg} \mathrm{L}^{-1}$ at $\mathrm{pH}$ 6.0. In the experiments to identify the effect of PP 
concentration (MWCNTs $=0.40 \mathrm{~g} \mathrm{~L}^{-1}$ and $\mathrm{T}=25^{\circ} \mathrm{C}$ ), the dye concentrations were 45.0 to $180.0 \mathrm{mg} \mathrm{L}^{-1}$. In the experiments to determine the effect of the dosage of the MWCNTs (PP concentration $=50.0 \mathrm{mg} \mathrm{L}^{-1}$ and $\mathrm{T}=25^{\circ} \mathrm{C}$ ), the dosages were 0.20 to $1.6 \mathrm{~g} \mathrm{~L}^{-1}$. In the experiments to establish the effect of temperature $\left(\right.$ MWCNTs $=1.04 \mathrm{~g} \mathrm{~L}^{-1}$ and PP concentration $\left.=75.0 \mathrm{mgL}^{-1}\right)$, seven different temperatures $\left(25,35,43,52,66,70\right.$, and $\left.76{ }^{\circ} \mathrm{C}\right)$ were evaluated. To obtain equilibrium data for the isotherm studies, $25 \mathrm{~mL}$ volumes of the PP solutions with different initial concentrations, ranging from 20 to $180 \mathrm{mg} \mathrm{L}^{-1}$, were in contact with $1.0 \mathrm{~g} \mathrm{~L}^{-1}$ of the MWCNTs in a closed, $50 \mathrm{~mL}$, glass, roundbottom flask at constant temperature. These experiments were brought at a constant initial $\mathrm{pH}$ value of 6.0 for a contact period of $25 \mathrm{~min}$. At the end of equilibration period, suspensions were centrifuged at $6000 \mathrm{rpm}$ for $3 \mathrm{~min}$, and the PP concentration in the supernatant was determined with HPLC (10.0 mg of PP was first weighed and then stirred with an amount of $40 \mathrm{~mL}$ of $0.05 \mathrm{M} \mathrm{NaOH}$ for a period of 12 hours. This volume was filled up to exactly $50 \mathrm{~mL}$ for purpose of drug concentration determination (after filtration) by HPLC). The amount of PP adsorbed ( $\left.\mathrm{mg} \mathrm{g}^{-1}\right)$ and the removal efficiency (\%) were computed as follows Equations (1) and (2):

$$
\begin{aligned}
& \% \mathrm{R}=\frac{\mathrm{C}_{0}-\mathrm{C}_{\mathrm{e}}}{\mathrm{C}_{0}} \times 100 \\
& \mathrm{q}_{\mathrm{t}}\left(m g g^{-1}\right)=\left(\mathrm{C}_{0}-\mathrm{C}_{\mathrm{e}}\right) \times\left(\frac{\mathrm{V}}{\mathrm{m}}\right)
\end{aligned}
$$

Where, $\mathrm{V}$ and $\mathrm{M}$ are represented to total volume $(\mathrm{L})$ and adsorbent amount $(\mathrm{g})$, respectively, $\mathrm{C}_{0}$ is initial concentration of $\mathrm{PP}\left(\mathrm{mg} \mathrm{L}^{-1}\right)$, and $\mathrm{C}_{\mathrm{e}}$ is equilibrium concentration of $\mathrm{PP}\left(\mathrm{mg} \mathrm{L}^{-1}\right)$.

\section{RESULTS AND DISCUSSION}

\subsection{Characterizations of MWCNTs}

Measurements related to X-ray diffraction (XRD) were made to precisely investigate the structure and the phase of MWCNTs according to chemical vapor deposition methodology. Fig. 1 shows the product's XRD pattern obtained at the conclusion of the process. Diffrac plus Assessment Program conducted XRD analysis of the sample, and the tag number of the International Centre for Diffraction Data was 00-058-1638. Such peaks were attributed to the carbon nanotubes in the software, according to this tag number. In the XRD curves of pure MWCNTT, the high peak at around $2 \theta=26^{\circ}$ is clearly visible. This peak is the $\left(\begin{array}{ll}0 & 0\end{array}\right)$ peak which has also been found in the structure of hexagonal graphite. The peak at around $42{ }^{\circ}$ was, in fact, the $\left(\begin{array}{lll}1 & 0 & 0\end{array}\right)$ peak.

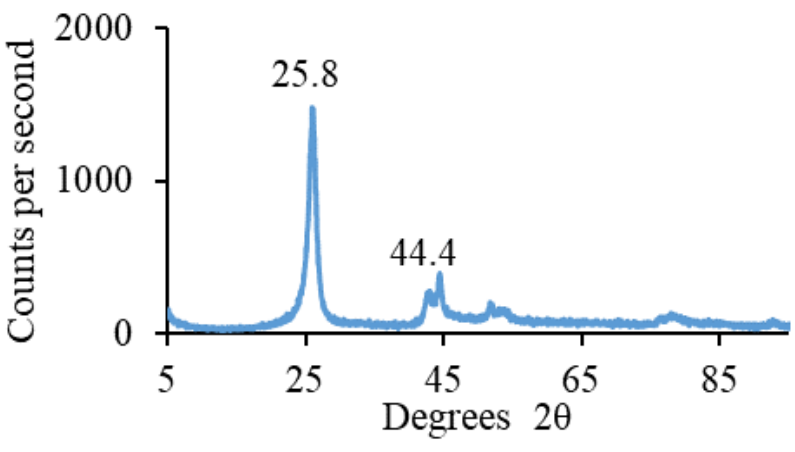

Figure 1. XRD pattern of synthesized carbon nanotubes by the CVD method.

\subsection{TEM image}

Figures 2 (A) and (B) illustrate the TEM images that had been adapted from the obtained produce. In Fig. 2(A) we can find the image of the MWCNTs synthesized before treating with acid. As for Fig. 2 (B) image, the TEM representation of the specimen after the acid phase was used to remove amorphous carbon structures. Dense MWCNTs were present in the structure, as both images indicate, and theaverage diameters of the tubes were $20-30 \mathrm{~nm}$ according to their TEM images, while their lengths were about 1-2 $\mu \mathrm{m}$. Observed at the ends of the MWCNTs were certain catalyst particles used during the synthesis process. In comparison, the MWCNTs were package-formed. Fig. 2(A) displays the very transparent sheets. These sheets had been amorphous carbon materials that during the decomposition of $\mathrm{C}_{2} \mathrm{H}_{2}$ gas could not be transformed into nanotubes. The bundle of MWCNTs also contained dense, black particles. The nano-iron particles that serve as catalysts are these particles. On these particles, MWCNTs nucleate and expand. Fig. 2(B) indicates that the amorphous carbon in the structure is not essentially present. This condition illustrates the effective removal of amorphous carbon from the powder of acid mixture. Moreover, it was clear that there were greatly decreased nano-dimensional iron particles, but none could have been said to be present. In fact, the acid mixture have no effect on the particles entangled in nanotube walls and which expanded with MWCNTs. In other terms, these particles were produced by the MWCNTs as protective medium.
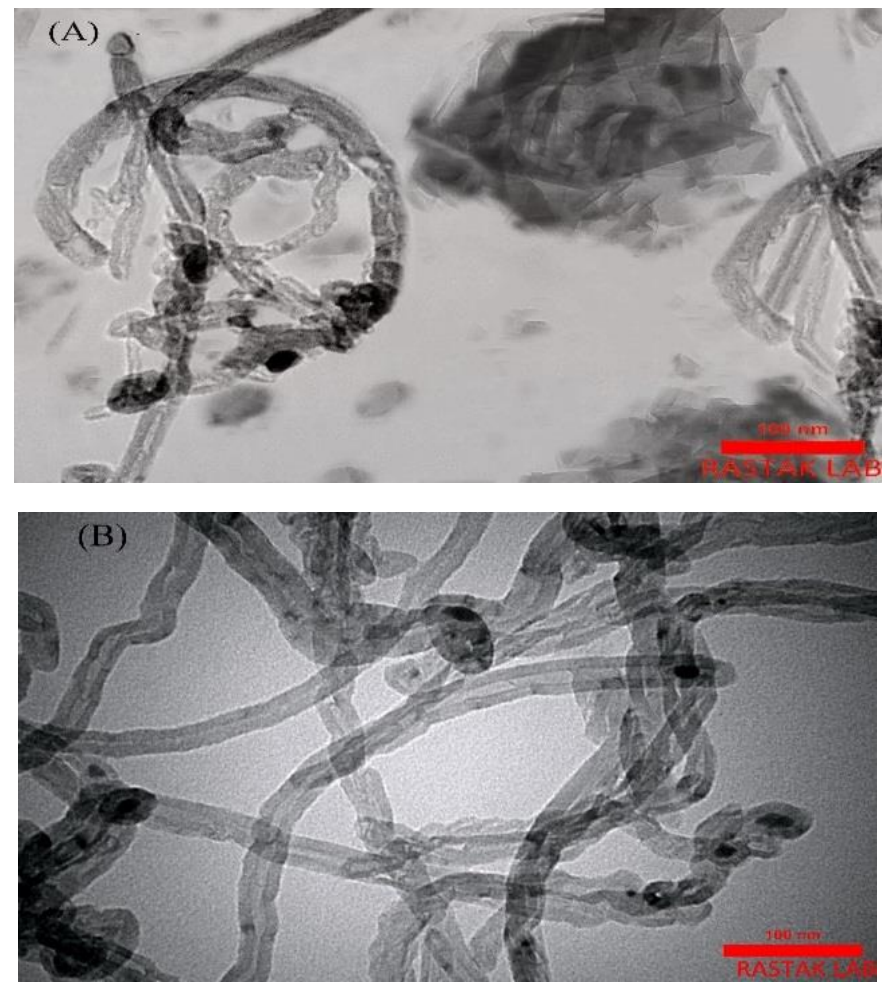

Figure 2. TEM images of the MWCNTs, synthesized (A) before treating with acid (B) after acid treatment.

\subsection{BET analyze, average pore diameter and total pore volume of the} MWCNT

Based on the nitrogen adsorption process, the single-point BET surface area for the MWCNT was calculated to be $98.7 \mathrm{~m}^{2} \mathrm{~g}^{-1}$; the average pores diameter was measured with a Belsorp mini II (Microtrac Bel Corp CO. Japan) apparatus to be $30.9 \mathrm{~nm}$. The volume of the pore was measured to be $0.764 \mathrm{~cm}^{3} \mathrm{~g}^{-1}$.

\subsection{FTIR analysis for examination of PP adsorption on MWCNTs}

FTIR research explored the potential of MWCNTs to remove PP by their adsorption. The functional groups on the MWCNT surface were defined using FTIR. Fig. 3 displays the MWCNTs, FTIR spectrum in optimal conditions both prior to (A) and after PP adsorption (B). The absorption peaks at 3,404 and 2986 $\mathrm{cm}^{-1}$ demonstrate the stretching vibration mode of $-\mathrm{OH}$ and $-\mathrm{CH}$, respectively. The wide peak at $3404 \mathrm{~cm}^{-1}$ can be caused by moisture adsorption or carboxylic acid bonding $\mathrm{OH}$. The bands in the 1550-1750 range can indeed be attributed to $\mathrm{C}=\mathrm{O}$ groups in different conditions (carboxylic acid, ketone/quinone) and to $\mathrm{C}=$ $\mathrm{C}$ in aromatic rings, while the bands in the range of $1300-950 \mathrm{~cm}^{-1}$ show the existence of $\mathrm{C}-\mathrm{O}$ bonds in different chemical surrounds.

The wavelength band at $1624 \mathrm{~cm}^{-1}$ is most likely attributable to the aromatic and unsaturated configuration of the $\mathrm{C}-\mathrm{C}$ bond, band around $1385 \mathrm{~cm}^{-1}$ attributed to alternating bands in the $\mathrm{C}-\mathrm{O}$ moiety region (e.g. $\mathrm{C}-\mathrm{O}-\mathrm{C}$ groupsstructural oxides, oxygen bridges, etc.) present in the FTIR propagation spectra of the MWCNTs [32]. The shifts in characteristic wavenumbers in the direction of lower wavenumbers remove and decrease the intensity some of peaks, indicating the electrostatic interaction between charged MWCNTs surfaces and groups in PP. 


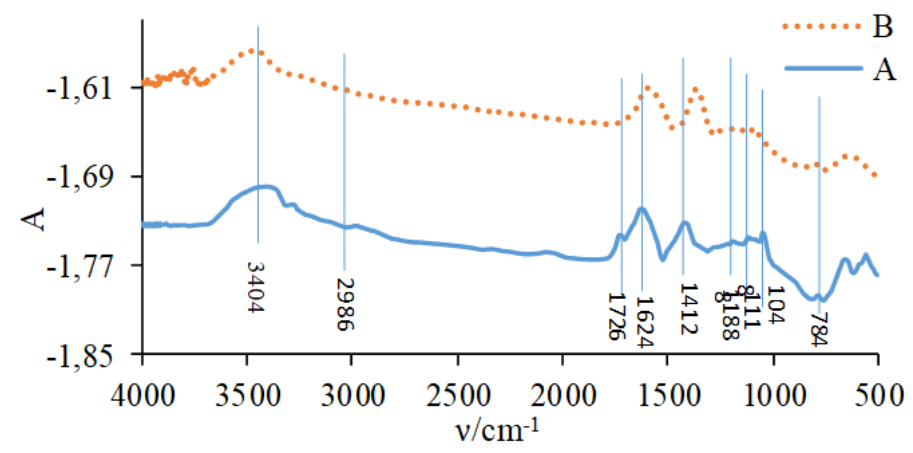

Figure 3. FT-IR spectra of (A) MWCNTs and (B) the adsorbed PP on the surface of MWCNTs.

\subsection{Effect of contact time}

The effect of contact time on the adsorption performance of the MWCNTs was studied. It was, the removal percentage of PP increased sharply with contact time for MWCNTs and with equilibrium being attained at $25 \mathrm{~min}$.

\section{6. the Effect of $\mathrm{pH}$ of solution on PP adsorption}

The $\mathrm{pH}$ of the system had a profound influence on the absorption of adsorbate molecules, presumably due to its influence on the surface properties of the adsorbent and on the ionization/dissociation of the adsorbate's molecules [33]. The $\mathrm{pKa}$ of $\mathrm{PP}$ is 3.9 , so it has a positive charge at the lower $\mathrm{pH}$ value and a negative charge at the higher $\mathrm{pH}$ value [34-36].The influence of $\mathrm{pH}$ on the removal of $\mathrm{PP}$ by adsorption on MWCNTs was studied by varying the $\mathrm{pH}$ values from 3.0 to 11.0, using a contact time of $25 \mathrm{~min}$ at each $\mathrm{pH}$ value at $25^{\circ} \mathrm{C}$. Fig. 4 shows the results. Accordingly, the amount of PP that was adsorbed was found to increase with the increase in $\mathrm{pH}$ from 3.0 to 6.0 , then decreased, and finally remained constant from $\mathrm{pH} 6.0$ to 9.0. In the end, the adsorption levels of PP decreased sharply as the $\mathrm{pH}$ increased from 10.0 to 11.0.

The point of zero charge ( $\mathrm{pH}_{\mathrm{PZC}}$ ) of the MWCNTs must be determined in order to understand the adsorption mechanism. The acid-base titration method was used to determine the $\mathrm{pH}_{\mathrm{PZC}}$ [37]. By adding either $\mathrm{HCl}$ or $\mathrm{NaOH}$, the $\mathrm{pH}$ of a $0.01 \mathrm{M} \mathrm{NaCl}$ solution was adjusted between 2.0 and 12.0. $0.15 \mathrm{~g}$ MWCNTs was added to each $50 \mathrm{~mL}$ of the solution when the $\mathrm{pH}$ for each solution was constant. In order to eliminate dissolved carbon dioxide $\left(\mathrm{CO}_{2}\right)$, nitrogen was bubbled through the solution at room temperature before the initial $\mathrm{pH}$ relatively stable. The final $\mathrm{pH}$ reached (in an orbital shaker after $24 \mathrm{~h}$ ) was assessed. It was then plotted against the initial $\mathrm{pH}$ value. At the junction point of the curve, the $\mathrm{pH}_{\text {Final- }}{ }^{-}$ $\mathrm{pH}_{\text {initial }}$ vs. $\mathrm{pH}_{\text {initial }}$ value has been determined. The $\mathrm{pH}_{\mathrm{PZC}}$ of the adsorbent is 9.4. When the solution $\mathrm{pH}$ is lower than $\mathrm{pH}_{\mathrm{pzc}}$ (9.4), the surface of MWCNTs had more positive charges, which enhanced the electrostatic interaction between the negatively charged PP and the positive adsorbent. The enhanced electrostatic attractive forces resulted in increased adsorption of molecules from the water. The surface of MWCNTs was negative when the $\mathrm{pH}$ solution is higher than pHpzc (9.4), thereby increasing the electrostatic repulsion between negatively charged PP and the negative adsorbent [38].

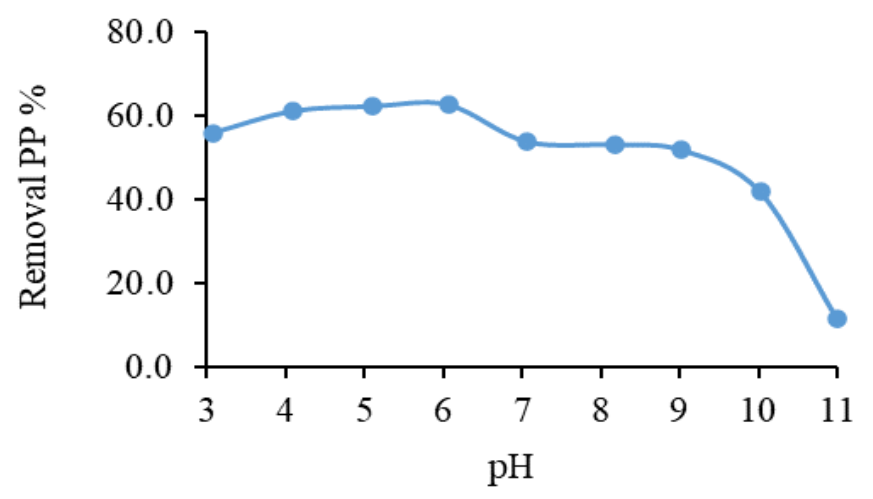

Figure 4. Effect of pH on PP removal, conc. PP $50 \mathrm{mg} \mathrm{L}^{-1}$, dosage adsorbent $0.4 \mathrm{~g} \mathrm{~L}^{-1}$, volume $25 \mathrm{~mL}$, contact time $25 \mathrm{~min}$, and temperature $25^{\circ} \mathrm{C}$.

\subsection{Effect of the dosage of the adsorbent}

The effect of the adsorbent's dosage on the capacity of the MWCNTs to remove PP from the solution was investigated with different dosages of the adsorbent in the range of $0.2-1.6 \mathrm{~g} \mathrm{~L}^{-1}$ at $25^{\circ} \mathrm{C}$, initial $\mathrm{pH}$ of 6.0 , and an initial dye concentration of $50 \mathrm{mg} \mathrm{L}^{-1}$. The amount of PP adsorbed increases from 40 $\%$ of PP to 94.2 for $1.0 \mathrm{~g} \mathrm{~L}^{-1}$ adsorbent. This is due to the increase in surface area resulting from the increase in adsorbent mass, thus increasing the number of active adsorption sites.

\subsection{Adsorption kinetics and Adsorption Equilibrium Studies}

The treatment of aqueous sample applied adsorption kinetic studies since these studies may provide useful information about the adsorption process mechanism [39]. In order to determine the rate constants of phenomena for purposes of investigating the pollutant adsorption mechanism on the adsorbent, Elovich [40], intra-particle diffusion [41], pseudo-first-order [42], and pseudo-secondorder [43] models were selected to match the sorption kinetic data obtained. The experimental kinetic data were calculated to explain detailed characteristics of the PP adsorption processes of MWCNTs. PP adsorption kinetic parameter on MWCNTs, were presented in Table 1

\subsubsection{Pseudo-first-order model}

The Lagergren, pseudo-first-order Equation is the most common kinetic Equation and it has only been used in this quick first stage. The Equation of the pseudo-first-order is given by:

$$
\log \left(q_{e}-q_{t}\right)=\log q_{e}-\frac{K_{1} t}{2.303}
$$

dwhere $\mathrm{q}_{\mathrm{e}}$ and $\mathrm{q}_{\mathrm{t}}$ are the quantity of species adsorbed at the same equilibrium and at any time $(\mathrm{t})$, respectively, per unit mass of adsorbents $\left(\mathrm{mg} \mathrm{g}^{-1}\right)$ while $\mathrm{k}_{1}$ is the pseudo-first-order sorption rate constant $\left(\mathrm{min}^{-1}\right)$. Fig. 5 (A) displays the linear diagram of the PP adsorption pseudo-first-order model on MWCNTs.

\subsubsection{Pseudo-second-order model}

The Equation of the pseudo-second order is given as follows:

$\frac{\mathrm{t}}{\mathrm{q}_{\mathrm{t}}}=\frac{1}{\mathrm{k}_{2} \mathrm{q}_{\mathrm{e}}^{2}}+\frac{\mathrm{t}}{\mathrm{q}_{\mathrm{e}}}$

where $\mathrm{k}_{2}$ is the pseudo-second-order sorption rate constant $\left(\mathrm{g} \cdot \mathrm{mg}^{-1} \cdot \mathrm{min}^{-1}\right)$. Fig. 5 (B) displays the results. The estimated $\mathrm{q}_{\mathrm{e}}$ values were more close to the experimental $\mathrm{q}_{\mathrm{e}}$ values and the correlation coefficient $(\mathrm{R})$ values were relatively higher $\left(\mathrm{R}^{2}>0.999\right)$ than the other kinetic models. Thus the pseudo-second-order kinetic model better suited MWCNTs to PP adsorption, which could be a ratecontrolling phase.

\subsubsection{Intra-particle diffusion model}

Weber and Morris intra-particle diffusion model [41] has been developed, which may be shown as:

$$
\mathrm{q}_{\mathrm{t}}=\mathrm{k}_{\mathrm{p}} \mathrm{t}^{1 / 2}+\mathrm{I}
$$

Where the quantity of PP adsorbed at time t (minutes) per unit weight of MWCNTs is $\mathrm{q}_{\mathrm{t}}\left(\mathrm{mg} \mathrm{g}^{-1}\right)$, the intra-particle diffusion rate constant is kid $\left(\mathrm{mg} \mathrm{g}^{-1}\right.$ $\mathrm{min}^{-1 / 2}$ ), and the intercept is $\mathrm{C}$. For measuring a diffusion-controlled reaction, the linear plot of $q_{t}$ versus $t^{1 / 2}$ is used. The rising $C$ values show that there is an improvement in molecule boundary layer thickness, which plays a significant role in the rate-limiting stage of surface adsorption [44]. Fig. 5 (C) shows the diagram of the PP adsorption intra-particle diffusion model on MWCNTs.

\subsubsection{Elovich model}

Another kinetic Equation for chemical sorption is defined by Zeldowitch. This is the linear shape of Elovich's Equation:

$$
\mathrm{q}_{\mathrm{t}}=1 / \beta \operatorname{Ln}(\mathrm{t})+1 / \beta \operatorname{Ln}(\alpha \beta)
$$

where $\mathrm{a}$ is the Elovich initial adsorption rate constant $\left(\mathrm{mg} \mathrm{g}^{-1} \mathrm{~min}^{-1}\right)$ and $\mathrm{b}$ is the desorption constant $\left(\mathrm{g} \mathrm{mg}^{-1}\right)$. 
Important parameters, such as Elovich maximum adsorption capacity and Elovich constant could be calculated from the slope and intercept of the Equation (6) and reported in Table 1 and result display in fig. 5 (D). The slope and intercept for Equation (6) can be determined using significant parameters, such as the Elovich maximum adsorption capacity and the Elovich constant. These have been laid out in Table 1. Table 1 also presents the coefficient of correlation $\left(\mathrm{R}^{2}\right)$ for PP and kinetic parameters. These data demonstrate clearly that the pseudosecond-order coefficients are nearer to 1.00 in comparison with pseudo-firstorder $\left(R^{2}=0.753\right)$, intra-particle diffusion $\left(R^{2}=0.605\right)$, and Elovich $\left(R^{2}=0.755\right)$ models.
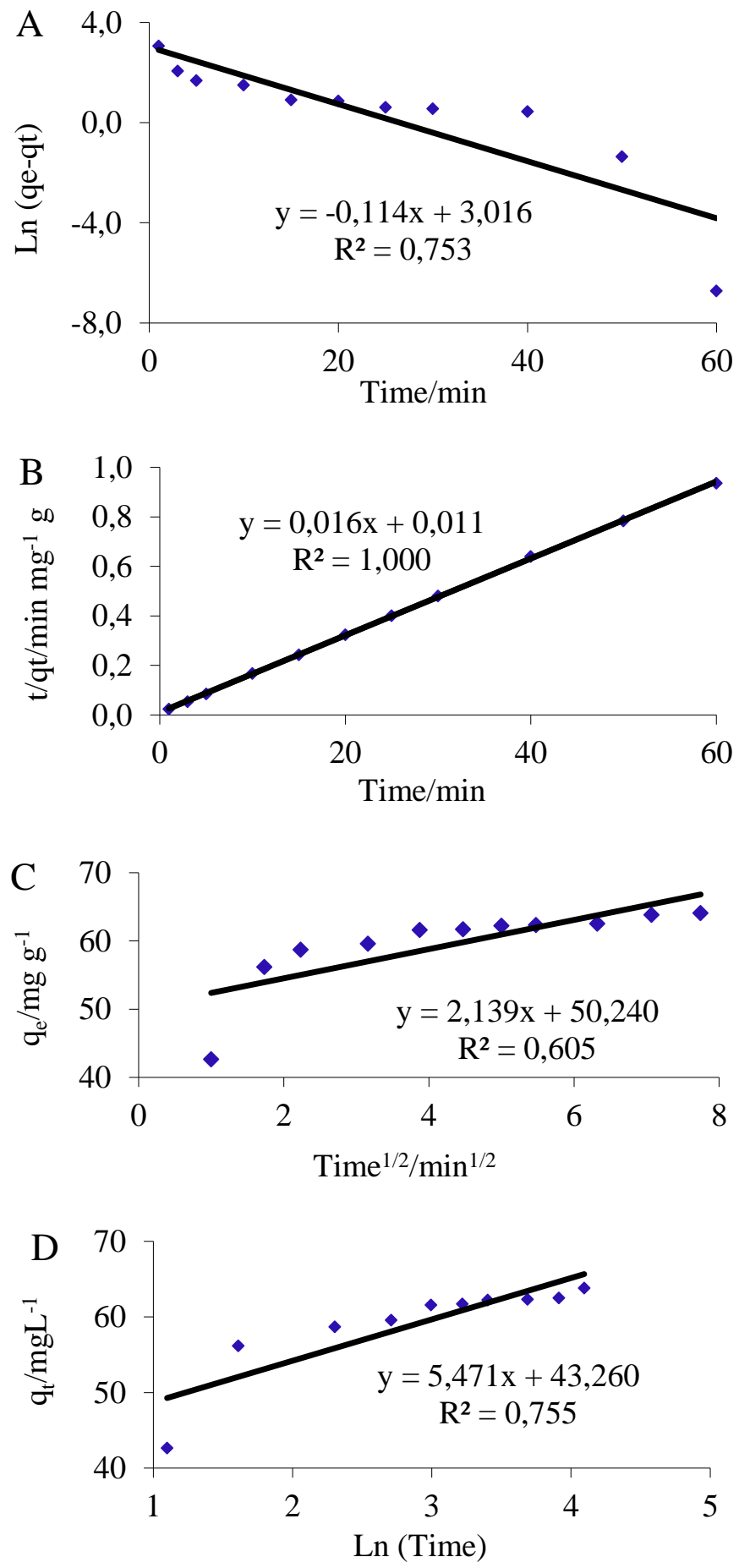

Figure 5. Adsorption kinetics. (A) pseudo-first-order kinetic plot, (B) pseudosecond-order kinetic plot, (C) intra-particle diffusion kinetic plot, and (D) Elovich kinetic plot of pantoprazole drug residue on MWCNTs, $\mathrm{pH}=6.0$, conc. PP $70 \mathrm{mg} \mathrm{L}^{-1}$, dosage adsorbent $1.0 \mathrm{~g} \mathrm{~L}^{-1}$, volume $25 \mathrm{~mL}$, and temperature $25^{\circ} \mathrm{C}$.
Table 1. PP adsorption kinetic parameter on MWCNTs ( $\mathrm{pH}=6.0$, conc. PP 70 $\mathrm{mg} \mathrm{L}^{-1}$, dosage adsorbent $1.0 \mathrm{~g} \mathrm{~L}^{-1}$, volume $25 \mathrm{~mL}$, and temperature $25^{\circ} \mathrm{C}$ ).

\begin{tabular}{|c|c|c|c|}
\hline Model & Equation & Parameters & Quantity \\
\hline \multirow{4}{*}{$\begin{array}{l}\text { Pseudo-first } \\
\text { order kinetic }\end{array}$} & \multirow{4}{*}{$\operatorname{Ln}\left(\mathrm{q}_{\mathrm{e}}-\mathrm{q}_{\mathrm{t}}\right)=\operatorname{Lnq}_{\mathrm{e}}-\mathrm{K}_{1} \mathrm{t}$} & $\mathrm{q}_{\mathrm{e}, \exp }\left(\mathrm{mg} \mathrm{g}^{-1}\right)$ & 64.1 \\
\hline & & $\mathrm{K}_{1}\left(\min ^{-1}\right)$ & 0.114 \\
\hline & & $\mathrm{q}_{\mathrm{e}, \mathrm{cal} .\left(\mathrm{mg} \mathrm{g}^{-1}\right)}$ & 20.41 \\
\hline & & $\mathrm{R}^{2}$ & 0.753 \\
\hline \multirow{3}{*}{$\begin{array}{l}\text { Pseudo-second } \\
\text { order kinetic }\end{array}$} & \multirow{3}{*}{$\mathrm{t} / \mathrm{q}_{\mathrm{t}}=1 / \mathrm{K}_{2} \mathrm{q}_{\mathrm{e}}^{2}+\mathrm{t} / \mathrm{q}_{\mathrm{e}}$} & $\mathrm{K}_{2}\left(\min ^{-1}\right)$ & 0.023 \\
\hline & & $\mathrm{q}_{\mathrm{e}} \mathrm{cal} .\left(\mathrm{mg} \mathrm{g}^{-1}\right)$ & 4.93 \\
\hline & & $\mathrm{R}^{2}$ & 1.000 \\
\hline \multirow{3}{*}{$\begin{array}{l}\text { Intra-particle } \\
\text { diffusion }\end{array}$} & \multirow{3}{*}{$\mathrm{q}_{\mathrm{t}}=\mathrm{K}_{\mathrm{id}} \mathrm{t}^{1 / 2}+\mathrm{C}$} & $\mathrm{K}_{\mathrm{id}}\left(\mathrm{mg} \mathrm{g}^{-1} \mathrm{~min}^{-1 / 2}\right)$ & 2.139 \\
\hline & & $\mathrm{C}\left(\mathrm{mg} \mathrm{g}^{-1}\right)$ & 50.24 \\
\hline & & $\mathrm{R}^{2}$ & 0.605 \\
\hline \multirow{3}{*}{ Elovich model } & \multirow{3}{*}{$\mathrm{q}_{\mathrm{t}}=1 / \beta \operatorname{Ln}(\mathrm{t})+1 / \beta \operatorname{Ln}(\alpha \beta)$} & $\beta\left(\mathrm{mg} \mathrm{g}^{-1}\right)$ & 0.183 \\
\hline & & $\alpha\left(\mathrm{mg} \mathrm{g}^{-1}\right)$ & 14862.6 \\
\hline & & $\mathrm{R}^{2}$ & 0.755 \\
\hline
\end{tabular}

\subsection{Adsorption isotherms}

Freundlich [45], Langmuir[46], Temkin [40], and Dubinin-Radushkevich isotherm models were used to research the relationship between the adsorbate and adsorbent concentration at equilibrium and the maximum adsorptive capacity at constant temperature [59]. The absorption function, surface properties, adsorbent inclination, and explanations of absorption experimental data were interpreted in the isotherm models. Fig. 6 shows the linear plots of isotherm models of Freundlich, Langmuir, Temkin, and Dubinin-Radushkevich adapted to the adsorption of PP on MWCNTs. All Freundlich, Langmuir, Temkin, and Dubinin-Radushkevich parameters derived from the plots are presented in Table 2 .

\subsubsection{Freundlich isotherm model}

The Freundlich isothermal model is based on the premise that on a heterogeneous surface, with contact between the adsorbed molecules, the adsorption of metal ions takes place by multilayer adsorption. This isotherm is derived from an empirical Equation that describes an adsorbent's exponential distribution of the adsorption nucleus [47]. While Langmuir isotherm was originally developed to demonstrate the adsorption of gas molecules on homogeneous surfaces, the action of solutions on solid surfaces was later further studied. [48].

The Freundlich model's linear shape employing logarithms is defined by the following Equation:

$$
\operatorname{Lnq}_{\mathrm{e}}=\mathrm{LnK}_{\mathrm{f}}+(1 / \mathrm{n}) \mathrm{LnC}_{\mathrm{e}}
$$

In Equation $7, \mathrm{q}_{\mathrm{e}}$ is the equilibrium adsorption capacity $\left(\mathrm{mg} \mathrm{g}^{-1}\right), \mathrm{Ce}$ is the equilibrium concentration of PP in solution $\left(\mathrm{mg} \mathrm{L}^{-1}\right), \mathrm{n}$ and $\mathrm{Kf}\left(\mathrm{mg} \mathrm{g}^{-1}\right)\left(\mathrm{mg} \mathrm{L}^{-1}\right)^{\mathrm{n}}$ are the isothermal adsorption constants of Freundlich acquired by Equation 7 from the intercept and slope.

An example of the adsorption variance from linearity is the value of $n\left(\mathrm{~g} \mathrm{~L}^{-1}\right)$ and the heterogeneity factor is the value of $1 / \mathrm{n}$. An $n$ value between 1 and 10 (i.e. $1 / \mathrm{n}<1$ ) implies a desirable adsorption value. For $\mathrm{n}=1$, there is linear adsorption; but for $\mathrm{n}=1$, adsorption will become a chemical process; for $\mathrm{n}=1$, adsorption then becomes physical process. $\mathrm{n}$ above $1(\mathrm{n}=3.891)$ was observed in this analysis, demonstrating that the adsorption of PP on MWCNTs is a physical process [49], and if $1 / \mathrm{n}$ below 1 a typical Langmuir isotherm is observed, cooperative adsorption occurs for $1 / \mathrm{n}$ above 1 [50]. Therefore, a typical Langmuir isotherm is the adsorption of PP on MWCNTs.

\subsubsection{Langmuir isotherm}

The Langmuir model suggests that adsorbate adsorption takes place on a homogeneous surface by monolayer adsorption, without any contact between the adsorbate at neighboring site [51]. The linear form of the isothermal model of Langmuir may be defined as:

$$
\mathrm{C}_{\mathrm{e}} / \mathrm{q}_{\mathrm{e}}=1 / \mathrm{K}_{\mathrm{L}} \mathrm{q}_{\mathrm{m}}+\mathrm{C}_{\mathrm{e}} / \mathrm{q}_{\mathrm{m}}
$$

$\mathrm{q}_{\mathrm{e}}$ in the Equation 8 presents the adsorption capacity at equilibrium $\left(\mathrm{m} \mathrm{g} \mathrm{g}^{-1}\right)$, and $\mathrm{q}_{\max }$ is the maximum adsorption capacity, $\mathrm{K}_{\mathrm{L}}$ is the Langmuir isotherm 
constant $\left(\mathrm{L} \mathrm{mg}^{-1}\right)$, while $\mathrm{Ce}$ is the equilibrium concentration of PP in solution $\left(\mathrm{mg} \mathrm{L} \mathrm{L}^{-1}\right) .1 / \mathrm{q}_{\max }$ and $\mathrm{K}_{\mathrm{L}}$ are constants which are obtained from regression Equation where $1 / \mathrm{q}_{\max }$ is intercept and $\mathrm{K}_{\mathrm{L}}$ is slope. The validity of the method of adsorption is defined in terms of the dimensionless factor of separation $\left(R_{L}\right)$, which is an integral function of the Langmuir model. The separation factor $\left(R_{L}\right)$ will have then been calculated with the following Equation (8):

$\mathrm{R}_{\mathrm{L}}=\frac{1}{1+\mathrm{K}_{\mathrm{L}} \mathrm{C}_{0}}$

where $\mathrm{C}_{0}$ is the initial concentration of PP. The RL value is an instance of the unfavorable $\left(\mathrm{R}_{\mathrm{L}}>1\right)$, linear $\left(\mathrm{R}_{\mathrm{L}}=1\right)$, desirable $\left(0<\mathrm{R}_{\mathrm{L}}<1\right)$ or irreversible $\left(\mathrm{R}_{\mathrm{L}}=\right.$ $0)$ isothermal and adsorption processes. For MWCNTs, the value was $0.24\left(\mathrm{R}_{\mathrm{L}}<\right.$ 1), suggesting that the adsorption of PP on this substance was beneficial.

\subsubsection{The Temkin Isotherm}

This isotherm requires a factor that takes adsorbent-adsorbate interactions directly into account. The model assumes that heat adsorption (temperature function) of all molecules in the layer will decrease linearly rather than logarithmically with coverage by overlooking the exceedingly low and broad value of concentrations [52,53]. Its derivation, as indicated in the Equation (10), is defined by a uniform distribution of binding energies (up to some limit binding energy) by plotting the sum of sorbed $\mathrm{q}_{\mathrm{e}}$ against $\ln \mathrm{C}_{\mathrm{e}}$ and calculating the constants from the slope and intercept. The following Equation (10) provides the model [54]:

$$
\mathrm{q}_{\mathrm{e}}=\mathrm{RT} / \mathrm{b} \operatorname{Ln}\left(\alpha \mathrm{C}_{\mathrm{e}}\right)
$$

This isotherm was simplified as follows [54,55]:

$$
\begin{aligned}
& \mathrm{q}_{\mathrm{e}}=\beta \mathrm{Ln} \alpha+\beta \mathrm{LnC}_{\mathrm{e}} \\
& \beta=\frac{\mathrm{RT}}{\mathrm{b}_{\mathrm{T}}} \\
& \alpha=\text { Temkin isotherm equilibrium binding constant }\left(\mathrm{L} \mathrm{g}^{-1}\right) \\
& \mathrm{b}_{\mathrm{T}}=\text { Temkin isotherm constant } \\
& \mathrm{R}=\text { universal gas constant }\left(8.314 \mathrm{Jmol}^{-1} \mathrm{~K}^{-1}\right) \\
& \mathrm{T}=\text { Temperature at } 298 \mathrm{~K} . \\
& \beta=\text { Constant related to heat of sorption }\left(\mathrm{J} \mathrm{mol}^{-1}\right)
\end{aligned}
$$

\subsubsection{Dubinin-Radushkevich isotherm model}

The Dubinin-Radushkevich isotherm is often used to demonstrate the adsorption mechanism on a heterogeneous surface with a Gaussian energy distribution. High-solute operations and the intermediate spectrum of concentration data have also been effectively fitted with the model [56]. DubininRadushkevich isotherm is expressed as follows:

The non-linear and linear Equation can be illustrated Eq. (13) and Eq. (14), respectively:

$$
\begin{aligned}
& \mathrm{q}_{\mathrm{e}}=\mathrm{q}_{\mathrm{m}} \exp \left(-\mathrm{K} \varepsilon^{2}\right) \\
& \mathrm{Lnq}_{\mathrm{e}}=\mathrm{Lnq}_{\mathrm{m}}-\mathrm{K} \varepsilon^{2}
\end{aligned}
$$

$\mathrm{q}_{\mathrm{e}}$ and $\mathrm{q}_{\mathrm{m}}$ are the amount of adsorbate in the adsorbent $\left(\mathrm{mg} \mathrm{g}^{-1}\right)$ and quantity of the PP adsorbed on the adsorbent $\left(\mathrm{mg} \mathrm{g}^{-1}\right)$, respectively, at equilibrium. $\mathrm{K}$ is the Dubinin-Radushkevich isotherm constant $\left(\mathrm{mol}^{2} \mathrm{k}^{-1} \mathrm{~J}^{-2}\right)$ and $\varepsilon$ is the DubininRadushkevich isotherm constant. The process was commonly used to discriminate between the physical and chemical adsorption of metal ions with its mean free energy, E mean adsorption energy, which can be determined by the relationships [57,58]:

$$
E=1 / \sqrt{2 K}
$$

In the meanwhile, the $\varepsilon$ parameter can be computed as:

$$
\varepsilon=R T \operatorname{Ln}\left(1+\frac{1}{C e}\right)
$$

$\mathrm{R}$ is gas constant $\left(8.314 \mathrm{~J} \mathrm{~mol}^{-1} \mathrm{~K}^{-1}\right)$, T represents temperature $(\mathrm{K})$, and $\mathrm{C}_{\mathrm{e}}$ is adsorbate equilibrium concentration $\left(\mathrm{mg} \mathrm{L}^{-1}\right)$. A chemical reaction happens in the case of $\mathrm{E}>8 \mathrm{~kJ} \mathrm{~mol}^{-1}$, where $\mathrm{E}<8 \mathrm{~kJ} \mathrm{~mol}^{-1}$ is a physical adsorption [59].

The effects of the isothermal adsorption parameters are presented in Table 2. The findings explicitly show that because the $\mathrm{R}^{2}$ values were far higher than those found for the Freundlich model, the adsorption equilibrium value matches well with the Langmuir model.

\begin{tabular}{|c|c|c|c|}
\hline Model & Equation & Parameters & Quantity \\
\hline \multirow{3}{*}{ Freundlich isotherm } & \multirow{3}{*}{$\operatorname{Ln} \mathrm{q}_{\mathrm{e}}=\ln \mathrm{K}_{\mathrm{F}}+(1 / \mathrm{n}) \ln \mathrm{C}_{\mathrm{e}}$} & $1 / \mathrm{n}$ & \begin{tabular}{|l|}
0.257 \\
\end{tabular} \\
\hline & & $\mathrm{K}_{\mathrm{F}}\left(\mathrm{L} \cdot \mathrm{mg}^{-1}\right)$ & 34.6 \\
\hline & & $\mathrm{R}^{2}$ & 0.998 \\
\hline \multirow{3}{*}{ Langmuir isotherm } & \multirow{3}{*}{$\mathrm{C}_{\mathrm{e}} / \mathrm{q}_{\mathrm{e}}=1 / \mathrm{K}_{\mathrm{L}} \mathrm{q}_{\mathrm{m}}+\mathrm{C}_{\mathrm{e}} / \mathrm{q}_{\mathrm{m}}$} & $\mathrm{q}_{\mathrm{m}}\left(\mathrm{mg} \mathrm{g}^{-1}\right)$ & 111.1 \\
\hline & & $\mathrm{K}_{\mathrm{L}}\left(\mathrm{L} \mathrm{mg}^{-1}\right)$ & 0.143 \\
\hline & & $\mathrm{R}^{2}$ & 0.987 \\
\hline \multirow{3}{*}{ Temkin isotherm } & \multirow{3}{*}{$\mathrm{q}_{\mathrm{e}}=\beta_{\mathrm{l}} \ln \mathrm{K}_{\mathrm{T}}+\beta_{\mathrm{l}} \ln \mathrm{C}_{\mathrm{e}}$} & $\beta_{1}$ & 2.41 \\
\hline & & $\mathrm{K}_{\mathrm{T}}\left(\mathrm{L} \cdot \mathrm{mg}^{-1}\right)$ & 662.5 \\
\hline & & $\mathrm{R}^{2}$ & 0.951 \\
\hline \multirow{4}{*}{$\begin{array}{l}\text { Dubinin-Radushkevich } \\
\text { isotherm model }\end{array}$} & \multirow{4}{*}{$\operatorname{Ln} \mathrm{q}_{\mathrm{e}}=\operatorname{Ln} \mathrm{q}_{\mathrm{m}}-\mathrm{K} \varepsilon^{2}$} & $\mathrm{q}_{\mathrm{m}}\left(\mathrm{mg} \mathrm{g}^{-1}\right)$ & 84.5 \\
\hline & & $\mathrm{K}$ & $1 \times 10^{-6}$ \\
\hline & & $\mathrm{E}\left(\mathrm{kJ} \mathrm{mol}^{-1}\right)$ & 707.1 \\
\hline & & $\mathrm{R}^{2}$ & 0.834 \\
\hline
\end{tabular}
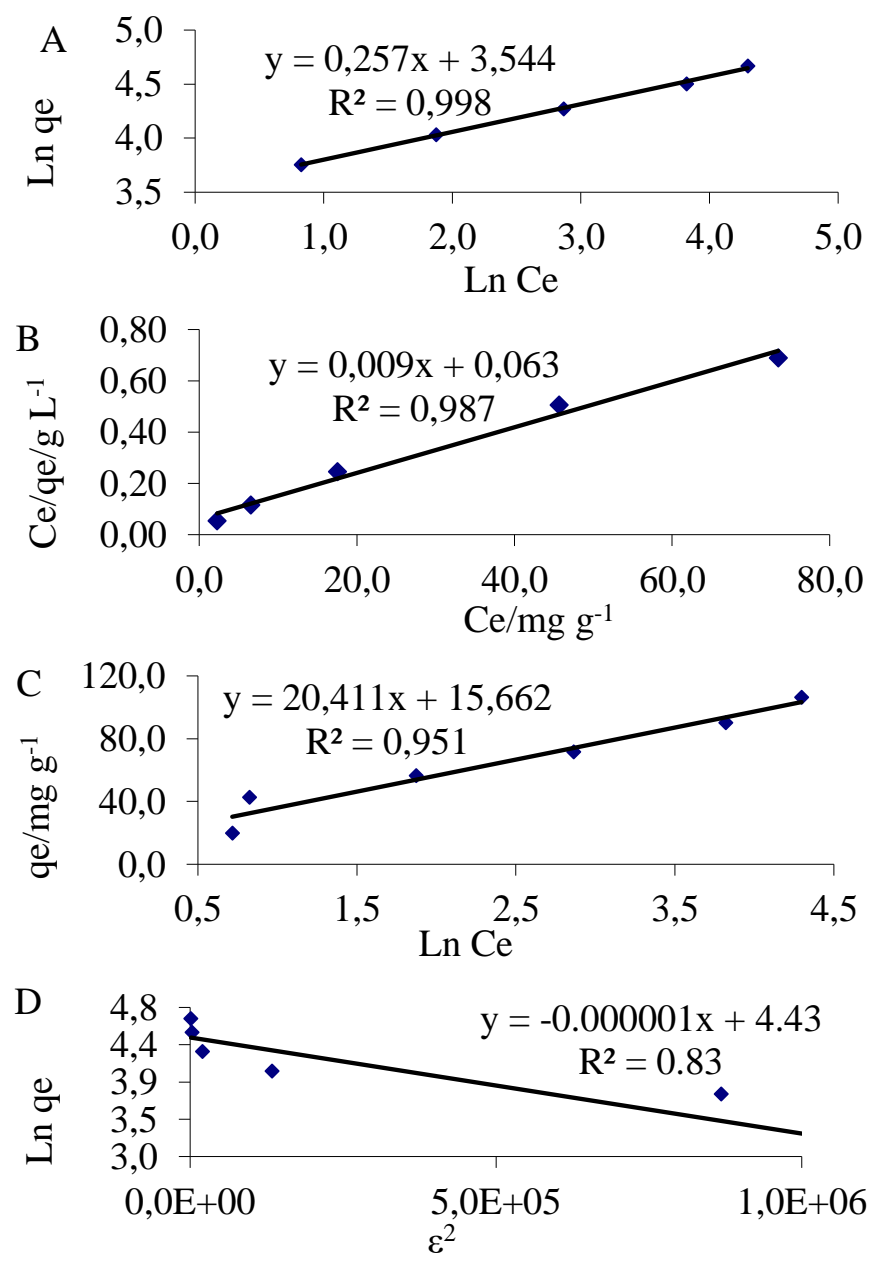

Figure 6. Adsorption isotherms. (A) Freundlich, (B) Langmuir, (C) Temkin, and (D) Dubinin-Radushkevich plots for adsorption of PP onto MWCNTs, $\mathrm{pH}=6.0$, dosage adsorbent $1.0 \mathrm{~g} \mathrm{~L}^{-1}$, volume $25 \mathrm{~mL}$, contact time $25 \mathrm{~min}$, and temperature $25^{\circ} \mathrm{C}$.

Table 2. Isotherm model parameters for the adsorption of PP on MWCNTs $\left(\mathrm{pH}=6.0\right.$, contact time $25 \mathrm{~min}$, dosage adsorbent $1.0 \mathrm{~g} \mathrm{~L}^{-1}$, volume $25 \mathrm{~mL}$, and temperature $25^{\circ} \mathrm{C}$ ). 


\subsection{Adsorption 3.10. thermodynamic studies}

The temperature effect of different temperatures from 298 to $349 \mathrm{~K}$ was studied. All other parameters were kept stable, with an initial PP concentration of $75.0 \mathrm{mg} \mathrm{L}^{-1}, 1.0 \mathrm{~g} \mathrm{~L}^{-1}$ MWCNT at $\mathrm{pH}$ 6.0. the result indicates that with the increase in temperature, the adsorption potential of MWCNTs decreases from $68.22 \mathrm{mg} \mathrm{g}^{-1}$ (89 percent removal) to $55.13 \mathrm{mg} \mathrm{g}^{-1}$ (71.9 percent), suggesting that the PP is exothermic by nature. With the increase in temperature, the decline in adsorption may be largely attributable to the weakening of the adsorptive forces between the active sites of the adsorbent and adsorbent species and even between the adsorbed adsorbent molecules. Related findings were obtained with phenol adsorption by organo transformed Tirebolu bentonite by senturk et al. [60]. Thermodynamic factors, including Gibbs free energy $\left(\Delta \mathrm{G}^{\circ}\right)$, enthalpy $\left(\Delta \mathrm{H}^{\circ}\right)$, and entropy $\left(\Delta \mathrm{S}^{\circ}\right)$, assessed the viability of the adsorption operation. From the following Equation (17), $\Delta \mathrm{G}^{\circ}$ was determined:

$$
\Delta \mathrm{G}^{\circ}=-\mathrm{R} \operatorname{Tn} \mathrm{K}_{\mathrm{d}}
$$

where $\mathrm{R}$ is the universal gas constant $\left(8.314 \mathrm{~J} \mathrm{~mol}^{-1} \mathrm{~K}^{-1}\right)$, $\mathrm{T}$ is the temperature $(\mathrm{K})$, and $\mathrm{K}_{\mathrm{d}}$ is the distribution coefficient. The following Equation (18) was used to determine the $\mathrm{K}_{\mathrm{d}}$ value:

$$
\mathrm{Kd}=\frac{q_{e}}{C_{e}}
$$

where $\mathrm{q}_{\mathrm{e}}$ and $\mathrm{C}_{\mathrm{e}}$ are the equilibrium concentration of PP on MWCNTs $\left(\mathrm{mg} \mathrm{L}^{-1}\right)$ and in the solution $\left(\mathrm{mg} \mathrm{L}^{-1}\right)$, respectively. The enthalpy $\left(\Delta \mathrm{H}^{\circ}\right)$, and entropy $\left(\Delta \mathrm{S}^{\circ}\right)$ of adsorption were estimated from the Equations below:

$\Delta G^{\circ}=\Delta H^{\circ}-T \Delta S^{\circ}$

This Equation can be written as:

$$
\operatorname{LnK}_{d}=\frac{\Delta \mathrm{S}^{\circ}}{\mathrm{R}}-\frac{\Delta \mathrm{H}^{\circ}}{\mathrm{RT}}
$$

From the Van't Hoff plot $\ln \mathrm{K}_{\mathrm{d}}$ against $1 / \mathrm{T}$, the entropy $\left(\Delta \mathrm{S}^{\circ} \mathrm{J} \mathrm{K} \mathrm{K}^{-1}\right)$ and enthalpy $\left(\Delta \mathrm{H}^{\circ} \mathrm{kJ}\right.$ mole $\left.{ }^{-1}\right)$ values for the adsorption of PP on MWCNTs at various temperatures were calculated and presented. In the temperature range of 298$349 \mathrm{~K}$, the negative values of $\Delta \mathrm{G}^{\circ}$ suggested that the adsorption mechanism was practicable and spontaneous. The negative value of the enthalpy verified the exothermic nature of the adsorption, which was also confirmed by a reduction in the temperature rise of the $\mathrm{PP}$ absorption value. Also, during adsorption of $\mathrm{PP}$ on MWCNTs, the negative value of the entropy indicated diminished randomness at the solid/liquid interface. Parameters of thermodynamic were presented in Table 3 .

Table 3. Thermodynamic parameters of $\mathrm{PP}$ adsorption by MWCNTs ( $\mathrm{pH}=6.0$,

\begin{tabular}{|c|c|c|c|}
\hline $\mathbf{T}\left({ }^{\circ} \mathrm{C}\right)$ & $\Delta \mathbf{G}^{\circ}\left(\mathbf{K j ~ m o l}^{-1}\right)$ & $\Delta \mathbf{S}^{\circ}\left(\mathbf{j ~ m o l}^{-1} \mathbf{K}^{-1}\right)^{*}$ & $\Delta \mathbf{H}^{\circ}\left(\mathrm{Kj} \mathrm{mol}^{-1}\right)^{*}$ \\
\hline 25 & -12.69 & \multirow{7}{*}{-15.94} & \multirow{7}{*}{-17.44} \\
\hline 35 & -12.53 & & \\
\hline 43 & -12.40 & & \\
\hline 52 & -12.26 & & \\
\hline 66 & -12.03 & & \\
\hline 70 & -11.97 & & \\
\hline 76 & -11.87 & & \\
\hline
\end{tabular}
contact time $25 \mathrm{~min}$, conc. PP $70 \mathrm{mg} \mathrm{L}^{-1}$, dosage adsorbent $1.0 \mathrm{~g} \mathrm{~L}^{-1}$, volume $25 \mathrm{~mL}$ ).

\footnotetext{
* Measured between 298 and $349 \mathrm{~K}$.
}

\subsection{Effect of ionic strength}

There are several kinds of electrolytes in industrial waste water and natural waters that have major effects on the adsorption mechanism, so it is necessary to measure the effects of ionic strength on the removal of PP from aqueous solutions. $\mathrm{NaCl}, \mathrm{Na}_{3} \mathrm{PO}_{4}, \mathrm{Na}_{2} \mathrm{SO}_{4}$ and $\mathrm{NaNO}_{3}$, widely found in water, were chosen as model salts in the current study to examine their effect on the adsorption of PP on MWCTs.

The adsorption experiments were performed by independently applying varying concentration ranging through $0.005-0.3 \mathrm{M}$ of $\mathrm{NaCl}, \mathrm{Na}_{3} \mathrm{PO} 4, \mathrm{Na}_{2} \mathrm{SO}_{4}$ and $\mathrm{NaNO}_{3}$ solutions to $75 \mathrm{mg} \mathrm{L}^{-1}$ of PP solutions containing $1.04 \mathrm{~g} \mathrm{~L}^{-1}$ of
MWCNTs. The latest method of adsorption has been extended to these solutions. The increase in the concentration of salt contributed to a decline in the adsorption of PP on MWCNTs.

The sum of PP absorption declined from 43.3 to $42.2,38.0,36.8$ and $33.8 \mathrm{mg}$ $\mathrm{g}^{-1}$ as the salt concentration rose from 0 to $0.3 \mathrm{M}$ and the percentage elimination performance decreased from 96.5 percent to 94.1 percent, 84.8 percent, 82.0 percent and 75.5 percent for $\mathrm{NaCl}, \mathrm{Na}_{3} \mathrm{PO}_{4}, \mathrm{Na}_{2} \mathrm{SO}_{4}$ and $\mathrm{NaNO}_{3}$ salts, respectively. These effects may be clarified: in the presence of these salts, the active sites of the adsorbent can be inhibited so that PP molecules are stopped from binding to the adsorbent surface. The removal performance of PP under the opposing salts tested was not substantially affected.

\section{CONCLUSION}

This study has shown that MWCNTs particles would remove PP from aqueous solutions efficiently. Efficient removal efficiency parameters including $\mathrm{pH}$, contact time and initial adsorbent amount were optimized, revealing optimum removal of $\mathrm{PP}$ at $\mathrm{pH}=6.0$ after $25.0 \mathrm{~min}$ when $0.026 \mathrm{~g}$ MWCNTs were used. To analyze the data corresponding to the adsorption of PP on the surface of MWCNTs, kinetic models were used. It was found that the pseudo second-order model for adsorption of PP on the surface of MWCNTs suggests the high data representation potential of this model. Adsorption equilibrium experiments found that MWCNTs adsorption data are effectively expressed by the Freundlich isotherm. As a result, a heterogeneous system was given, which was represented by physical adsorption. The thermodynamic mechanism of adsorption has been explored. By raising the temperature, the adsorption of PP on MWCNTs decreased. The exothermic nature of the adsorption was demonstrated by the negative value of $\Delta \mathrm{H}^{\circ}\left(-17,44 \mathrm{KJ} \mathrm{mol}^{-1}\right)$. Also during adsorption of PP on MWCNTs, the negative value of $\Delta \mathrm{S}^{\circ}\left(15.94 \mathrm{~J} \mathrm{~mol}^{-1} \mathrm{~K}^{-1}\right)$ indicated reduced randomness at the solid/liquid interface. The amount of $\mathrm{PP}$ absorption decreased as the concentration of $\mathrm{NaCl}, \mathrm{Na}_{3} \mathrm{PO}_{4}, \mathrm{Na}_{2} \mathrm{SO}_{4}$ and $\mathrm{NaNO}_{3}$ salts increased.

\section{ACKNOWLEDGMENT}

The authors grateful from Research Council of the Islamic Azad University of Firozabad for their financial support.

\section{REFERENCES}

1. Ali I, Al-Othman ZA, Alharbi OML. Uptake of pantoprazole drug residue from water using novel synthesized composite iron nano adsorbent. J Mol Liq. Elsevier; 2016;218:465-72.

2. Zare MA, Husain SW, Tehrani MS, Azar PA. Pentaazatetraethylene supported polyacrylamide (PAA-N5) as a novel adsorbent for the efficient removal of industrial dyes from aqueous solutions: adsorption isotherms and kinetics. Monatshefte für Chemie-Chemical Mon. Springer; 2017;148:1917.

3. Khudhair AR, Sherazi STH, Al-Baiati MN. Adsorption of methylene blue from aqueous solutions by using a novel nano co-polymer. AIP Conf Proc. AIP Publishing LLC; 2020. p. 30021.

4. Sarkar KK, Majee S, Pathak U, Mandal DD, Mandal T. Design and development of an integrated treatment system for pharmaceutical waste with toxicological study. Desalin Water Treat. 2019;5:75-85.

5. Cavalcanti EB, Garcia-Segura S, Centellas F, Brillas E. Electrochemical incineration of omeprazole in neutral aqueous medium using a platinum or boron-doped diamond anode: degradation kinetics and oxidation products. water Res. Elsevier; 2013;47:1803-15.

6. Sengupta A, Gupta NK. MWCNTs based sorbents for nuclear waste management: a review. J Environ Chem Eng. Elsevier; 2017;5:5099-114.

7. Ali I, Aboul-Enein HY, Kummerer K. Analyses of drugs and pharmaceuticals in the environment. Biophys Process Anthropog Org Compd Environ Syst. Wiley Online Library; 2011;439-62.

8. Heberer T. Occurrence, fate, and removal of pharmaceutical residues in the aquatic environment: a review of recent research data. Toxicol Lett. Elsevier; 2002;131:5-17.

9. Zhang Y, Geißen S-U, Gal C. Carbamazepine and diclofenac: removal in wastewater treatment plants and occurrence in water bodies. Chemosphere. Elsevier; 2008;73:1151-61.

10. de García SO, Pinto GP, Encina PG, Mata RI. Consumption and occurrence of pharmaceutical and personal care products in the aquatic environment in Spain. Sci Total Environ. Elsevier; 2013;444:451-65.

11. Kosma CI, Lambropoulou DA, Albanis TA. Analysis, occurrence, fate and risks of proton pump inhibitors, their metabolites and transformation products 
in aquatic environment: A review. Sci Total Environ. Elsevier; 2016;569:732-50.

12. Barreiro JC, Vanzolini KL, Cass QB. Direct injection of native aqueous matrices by achiral-chiral chromatography ion trap mass spectrometry for simultaneous quantification of pantoprazole and lansoprazole enantiomers fractions. J Chromatogr A. Elsevier; 2011;1218:2865-70.

13. Gracia-Lor E, Sancho J V, Serrano R, Hernández F. Occurrence and removal of pharmaceuticals in wastewater treatment plants at the Spanish Mediterranean area of Valencia. Chemosphere. Elsevier; 2012;87:453-62.

14. Roy N, Alex SA, Chandrasekaran N, Mukherjee A, Kannabiran K. A comprehensive update on antibiotics as an emerging water pollutant and their removal using nano-structured photocatalysts. J Environ Chem Eng. Elsevier; $2020 ; 104796$.

15. Leeladevi K, Kumar JV, Arunpandian M, Thiruppathi M, Nagarajan ER. Investigation on photocatalytic degradation of hazardous chloramphenicol drug and amaranth dye by $\mathrm{SmVO} 4$ decorated g-C3N4 nanocomposites. Mater Sci Semicond Process. Elsevier; 2020;105563.

16. Ali A, Shoeb M, Li Y, Li B, Khan MA. Enhanced photocatalytic degradation of antibiotic drug and dye pollutants by graphene-ordered mesoporous silica (SBA 15)/TiO2 nanocomposite under visible-light irradiation. J Mol Liq. Elsevier; 2020;114696.

17. Nakada N, Shinohara H, Murata A, Kiri K, Managaki S, Sato N, et al. Removal of selected pharmaceuticals and personal care products (PPCPs) and endocrine-disrupting chemicals (EDCs) during sand filtration and ozonation at a municipal sewage treatment plant. Water Res. Elsevier; 2007;41:437382.

18. Pompei CME, Campos LC, da Silva BF, Fogo JC, Vieira EM. Occurrence of PPCPs in a Brazilian water reservoir and their removal efficiency by ecological filtration. Chemosphere. Elsevier; 2019;226:210-9.

19. Wang L, Albasi C, Faucet-Marquis V, Pfohl-Leszkowicz A, Dorandeu C, Marion B, et al. Cyclophosphamide removal from water by nanofiltration and reverse osmosis membrane. Water Res. Elsevier; 2009;43:4115-22.

20. Dolar D, Pelko S, Košutić K, Horvat AJM. Removal of anthelmintic drugs and their photodegradation products from water with RO/NF membranes. Process Saf Environ Prot. Elsevier; 2012;90:147-52.

21. Oberoi AS, Jia Y, Zhang H, Khanal SK, Lu H. Insights into the fate and removal of antibiotics in engineered biological treatment systems: a critical review. Environ Sci Technol. ACS Publications; 2019;53:7234-64.

22. Kanaujiya DK, Paul T, Sinharoy A, Pakshirajan K. Biological treatment processes for the removal of organic micropollutants from wastewater: a review. Curr Pollut Reports. Springer; 2019;5:112-28.

23. Quesada HB, Baptista ATA, Cusioli LF, Seibert D, de Oliveira Bezerra C, Bergamasco R. Surface water pollution by pharmaceuticals and an alternative of removal by low-cost adsorbents: A review. Chemosphere. Elsevier; 2019;222:766-80.

24. Mlunguza NY, Ncube S, Mahlambi PN, Chimuka L, Madikizela LM. Adsorbents and removal strategies of non-steroidal anti-inflammatory drugs from contaminated water bodies. J Environ Chem Eng. Elsevier; 2019;7:103142.

25. Ali I, Gupta VK. Advances in water treatment by adsorption technology. Nat Protoc. Nature Publishing Group; 2006;1:2661.

26. Ali I. Water treatment by adsorption columns: evaluation at ground level. Sep Purif Rev. Taylor \& Francis; 2014;43:175-205.

27. Dehmolaei A, Vadi M. Comparative Study of Adsorption Isotherms of Vitamin C on Multi Wall and Single Wall Carbon Nanotube. Orient J Chem. 2014;30:233-6.

28. Kyzas GZ, Deliyanni EA. Modified activated carbons from potato peels as green environmental-friendly adsorbents for the treatment of pharmaceutical effluents. Chem Eng Res Des. Elsevier; 2015;97:135-44.

29. Rasheed T, Bilal M, Hassan AA, Nabeel F, Bharagava RN, Ferreira LFR, et al. Environmental threatening concern and efficient removal of pharmaceutically active compounds using metal-organic frameworks as adsorbents. Environ Res. Elsevier; 2020;109436.

30. Karimi-Maleh H, Shafieizadeh M, Taher MA, Opoku F, Kiarii EM, Govender $\mathrm{PP}$, et al. The role of magnetite/graphene oxide nano-composite as a highefficiency adsorbent for removal of phenazopyridine residues from water samples, an experimental/theoretical investigation. J Mol Liq. Elsevier; 2020;298:112040.

31. Asfaram A, Ghaedi M, Azqhandi MHA, Goudarzi A, Dastkhoon M. Statistical experimental design, least squares-support vector machine (LSSVM) and artificial neural network (ANN) methods for modeling the facilitated adsorption of methylene blue dye. RSC Adv. Royal Society of Chemistry; 2016;6:40502-16.

32. Stobinski L, Lesiak B, Kövér L, Tóth J, Biniak S, Trykowski G, et al Multiwall carbon nanotubes purification and oxidation by nitric acid studied by the FTIR and electron spectroscopy methods. J Alloys Compd. Elsevier; 2010;501:77-84.

33. Dalvand A, Nabizadeh R, Ganjali MR, Khoobi M, Nazmara S, Mahvi AH Modeling of Reactive Blue 19 azo dye removal from colored textile wastewater using L-arginine-functionalized $\mathrm{Fe} 3 \mathrm{O} 4$ nanoparticles: Optimization, reusability, kinetic and equilibrium studies. J Magn Magn Mater. Elsevier; 2016;404:179-89.

34. Kromer W. Similarities and differences in the properties of substituted benzimidazoles: a comparison between pantoprazole and related compounds. Digestion. Karger Publishers; 1995;56:443-54.

35. El-Sherif ZA, Mohamed AO, El-Bardicy MG, El-Tarras MF. Reversed-phase high performance liquid chromatographic method for the determination of lansoprazole, omeprazole and pantoprazole sodium sesquihydrate in presence of their Acid-induced degradation products. Chem Pharm Bull. The Pharmaceutical Society of Japan; 2006;54:814-8.

36. Senn-Bilfinger J, Krueger U, Sturm E, Figala V, Klemm K, Kohl B, et al. (H+-K+)-ATPase inhibiting 2-[(2-pyridylmethyl) sulfinyl] benzimidazoles. 2 . The reaction cascade induced by treatment with acids. Formation of $5 \mathrm{H}$ pyrido [1', 2': 4, 5][1, 2, 4] thiadiazino [2, 3-a] benzimidazol-13-ium salts and their reactions with thiols. J Org Chem. ACS Publications; 1987;52:4582-92.

37. Danish M, Hashim R, Ibrahim MNM, Sulaiman O. Characterization of physically activated acacia mangium wood-based carbon for the removal of methyl orange dye. BioResources. 2013;8:4323-39.

38. Wang P, Cao M, Wang C, Ao Y, Hou J, Qian J. Kinetics and thermodynamics of adsorption of methylene blue by a magnetic graphene-carbon nanotube composite. Appl Surf Sci. Elsevier; 2014;290:116-24.

39. Chen Z, Fu J, Wang M, Wang X, Zhang J, Xu Q. Adsorption of cationic dye (methylene blue) from aqueous solution using poly (cyclotriphosphazene-co4, 4'-sulfonyldiphenol) nanospheres. Appl Surf Sci. Elsevier; 2014;289:495501 .

40. Aharoni C, Ungarish M. Kinetics of activated chemisorption. Part 2.Theoretical models. J Chem Soc Faraday Trans 1 Phys Chem Condens Phases. Royal Society of Chemistry; 1977;73:456-64.

41. Weber WJ, Morris JC. Kinetics of adsorption on carbon from solution. J Sanit Eng Div. ASCE; 1963;89:31-60.

42. Lagergren S, Lagergren S, Lagergren SY, Sven K. Zurtheorie der sogenannten adsorption gelösterstoffe. 1898;

43. Ho YS, McKay G. Pseudo-second order model for sorption processes. Process Biochem [Internet]. 1999;34:451-65. Available from: http://www.sciencedirect.com/science/article/pii/S0032959298001125

44. Nakkeeran E, Saranya N, Giri Nandagopal MS, Santhiagu A, Selvaraju N. Hexavalent chromium removal from aqueous solutions by a novel powder prepared from Colocasia esculenta leaves. Int J Phytoremediation. Taylor \& Francis; 2016;18:812-21.

45. Freundlich HMF. Over the adsorption in solution. J Phys Chem. 1906;57:1100-7.

46. Langmuir I. The adsorption of gases on plane surfaces of glass, mica and platinum. J Am Chem Soc. ACS Publications; 1918;40:1361-403.

47. Freundlich H. Über die Adsorption in Lösungen. Habilitationsschrift durch welche... zu haltenden Probevorlesung" Kapillarchemie und Physiologie" einladet Dr. Herbert Freundlich. W. Engelmann; 1906.

48. Khayyun TS, Mseer AH. Comparison of the experimental results with the Langmuir and Freundlich models for copper removal on limestone adsorbent. Appl Water Sci. Springer; 2019;9:170.

49. Kumar PS, Ramalingam S, Sathyaselvabala V, Kirupha SD, Murugesan A, Sivanesan S. Removal of cadmium (II) from aqueous solution by agricultural waste cashew nut shell. Korean J Chem Eng. Springer; 2012;29:756-68.

50. Fytianos K, Voudrias E, Kokkalis E. Sorption-desorption behaviour of 2, 4dichlorophenol by marine sediments. Chemosphere. Elsevier; 2000;40:3-6.

51. Langmuir I. The constitution and fundamental properties of solids and liquids. II. Liquids. J Am Chem Soc. ACS Publications; 1917;39:1848-906.

52. Foo KY, Hameed BH. Insights into the modeling of adsorption isotherm systems. Chem Eng J. Elsevier; 2010;156:2-10.

53. Gehlot G, Verma S, Sharma S, Mehta N. Adsorption isotherm studies in the removal of malachite green dye from aqueous solution by using coal fly ash. Int J Chem Stud. 2015;3:42-4.

54. Tempkin MI, Pyzhev V. Kinetics of ammonia synthesis on promoted iron catalyst. Acta Phys Chim USSR. 1940;12:327.

55. Akkaya G, Özer A. Biosorption of Acid Red 274 (AR 274) on Dicranella varia: Determination of equilibrium and kinetic model parameters. Process Biochem. 2005;40:3559-68.

56. Ayawei N, Ebelegi AN, Wankasi D. Modelling and Interpretation of Adsorption Isotherms. Guo W, editor. J Chem [Internet]. Hindawi; 2017;2017:3039817. Available from: https://doi.org/10.1155/2017/3039817 
57. Dubinin Mm. The potential theory of adsorption of gases and vapors for adsorbents with energetically nonuniform surfaces. Chem Rev. ACS Publications; 1960;60:235-41.

58. Hobson JP. Physical adsorption isotherms extending from ultrahigh vacuum to vapor pressure. J Phys Chem. ACS Publications; 1969;73:2720-7.
59. Chopra I, Singh SB. Kinetics and equilibrium study for adsorptive removal of cationic dye using agricultural waste-raw and modified cob husk. Int J Environ Anal Chem. Taylor \& Francis; 2020;1-22.

60. Senturk HB, Ozdes D, Gundogdu A, Duran C, Soylak M. Removal of phenol from aqueous solutions by adsorption onto organomodified Tirebolu bentonite: Equilibrium, kinetic and thermodynamic study. J Hazard Mater. Elsevier; 2009; 172:353-62. 